胃体部から底部を占める異所性扁平上皮より発生したと 考えられる胃原発性扁平上皮癌の 1 例

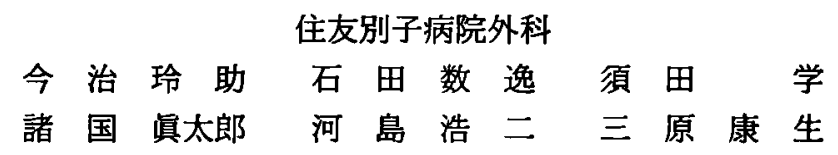

症例は29藏男性. 血便の精査中, 胃透視, 内視鏡検査にて胃体部を中心に Borr IV 型 様病変あり生検にて扁平上皮癌と診断し胃全摘, リンパ節郭清術を施行した，病理組織 学的所見では，噴門部の一部を除いて胃底部から体部は異所性扁平上皮組織により占め られ，その中に扁平上皮癌が認められた，腺癌組織の混在は認めなかった．胃癌取扱い 規約による特殊型の扁平上皮癌は, 腺癌が扁平上皮化生したとする説が広く支持されて いるが, 本症例では, 胃内異所性扁平上皮組織の癌化と考えられた。

索引用語：早期胃癌, 胃扁平上皮癌, 異所性扁平上皮

\section{緒 言}

胃原発性の上皮性悪性腫瘍の大部分は腺癌であり扁 平上皮癌は極めて稀である. その発生様式として腺癌 の扁平上皮化という説が比較的支持されているが，今 回われわれは，異所性扁平上皮より発生したと考えら れる胃原発性扁平上皮癌の 1 例を経験したので, 若干 の文献的考察を加え報告する。

患者：29歳, 男性.

$$
\text { 症例 }
$$

主訴：血便.

既往歴：17歳時 $\mathrm{A}$ 型肝炎。

家族歴：特記すべきことなし.

現病歴：1993年 2 月ごろより血便が出現。その後症 状治まるも，4月より再度出現し, 近医受診, 胃透視, 胃内視鏡検查にて胃扁平上皮癌と診断され，当科紹介 された.

入院時現症：貧血および黄疸を認めず。心肺には聴 診上異常所見を認めず．腹部は心瓫部に軽度圧痛を認 めた.

入院時検査成綨：CRP と腫煬マーカーSCC の軽度 上昇を認めた（表 1 )。

上部消化管造影所見：体中部から底部にかけて，大 筀側の壁の進展不良と硬化像を示し, 透視上は Borr IV 型様の病変が疑われた（図 1 ).
表 1 入院時血流梌查所見

\begin{tabular}{lc|lr}
\hline CBC & & CRP & $1.6 \mathrm{mg} / \mathrm{dl}$ \\
WBC & $7,500 / \mathrm{mm}^{3}$ & GOT & $30 \mathrm{IU} / \mathrm{L}$ \\
$\mathrm{RBC}$ & $590 \times 10^{4} / \mathrm{mm}^{3}$ & GPT & $29 \mathrm{IU} / \mathrm{L}$ \\
$\mathrm{Ht}$ & $42.1 \%$ & ALP & $433 \mathrm{IU} / \mathrm{L}$ \\
$\mathrm{Hb}$ & $12.5 \mathrm{~g} / \mathrm{dl}$ & $\mathrm{ChE}$ & $0.83 \Delta \mathrm{PH}$ \\
$\mathrm{Plt}$ & $21.9 \times 10^{4} / \mathrm{mm}^{3}$ & $\gamma-\mathrm{GTP}$ & $129 \mathrm{IU} / \mathrm{L}$ \\
血液生化学 & & T. Bil & $0.57 \mathrm{mg} / \mathrm{dl}$ \\
$\mathrm{Na}$ & $140 \mathrm{mEq} / \mathrm{L}$ & D. Bil & $0.15 \mathrm{mg} / \mathrm{dl}$ \\
$\mathrm{K}$ & $4.1 \mathrm{mEq} / \mathrm{L}$ & AMY & $90 \mathrm{IU} / \mathrm{L}$ \\
$\mathrm{Cl}$ & $103 \mathrm{mEq} / \mathrm{L}$ & Tumor marker \\
$\mathrm{Ca}$ & $4.3 \mathrm{mEq} / \mathrm{L}$ & CEA & $1.0 \mathrm{ng} / \mathrm{ml}$ \\
$\mathrm{BUN}$ & $12 \mathrm{mg} / \mathrm{dl}$ & SCC & $3.0 \mathrm{ng} / \mathrm{ml}$ \\
$\mathrm{CRN}$ & $0.6 \mathrm{mg} / \mathrm{dl}$ & CA19-9 & $4 \mathrm{U} / \mathrm{ml}$ \\
\hline \multicolumn{2}{r}{}
\end{tabular}

胃内視鏡所見：全体に進展不良であり，胃体下部よ り噴門まで後壁寄りに, 辺緑不整, 易出血性の隆起性 病変を認めた (図 2). 同部の生検より扁平上皮癌と診 断した。以上より1993年 5 月10日手術を施行した。

手術所見：腹水, 腹膜播腫, 肝転移等認めず胃大彎

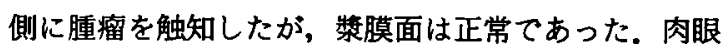
所見は, $\mathrm{S}_{0} \mathrm{P}_{0} \mathrm{H}_{0} \mathrm{~N}_{0}$, Stage I で根治手術可能と判断し, 胃全摘, 脾臓合併切除を行い 2 群までのリンパ節を郭 清した。

摘出標本所見：胃体中部より胃底部にかけて大きさ $80 \times 65 \times 20 \mathrm{~mm}$ の腫瘤を認め, 体中部より幽門にかけ て，粘膜の不整を認めた（図 3 ).

病理組織学的所見：図 4a は, 扁平上皮の部位であ 


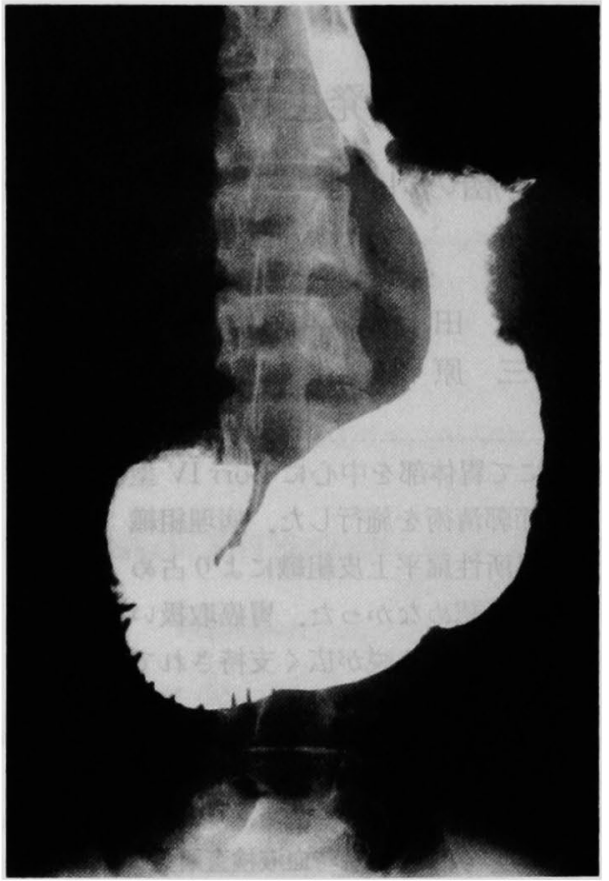

図 1 上部消化管造影所見：体中部から底部にかけ て，大彎側の壁の進展不良と硬化像を認める。

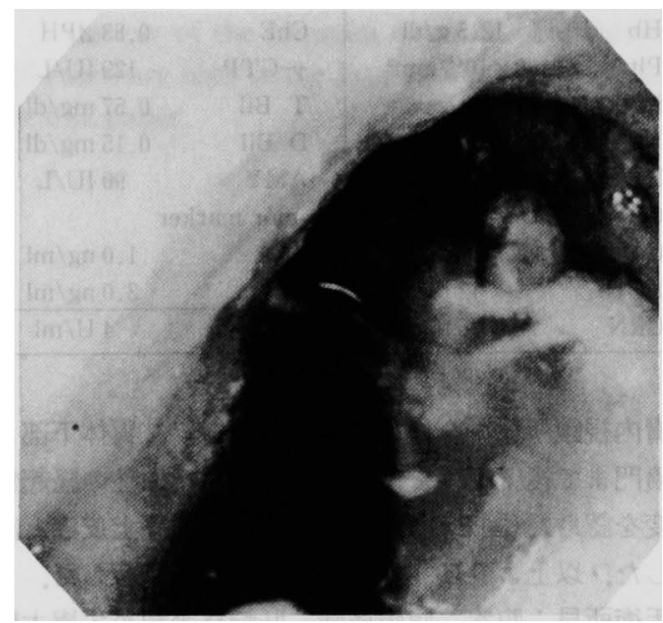

図 2 胃内視鏡所見：胃体下部より噴門,後壁寄りに， 辺縁不整, 易出血性の隆起性病変を認める。

るが，基底膜への浸潤，核の異型性は認められず，基 底膜から棘細胞への分化を認める. 図 $4 \mathrm{~b}$ は, 扁平上皮 癌の部位であるが, 索状の浸潤増殖とパールフォー メーションを認める. 図 4cでは, 細胞異型, 間質に及 ぶ浸潤, 孤細胞角化, 層分化を認める. 組織学的には,

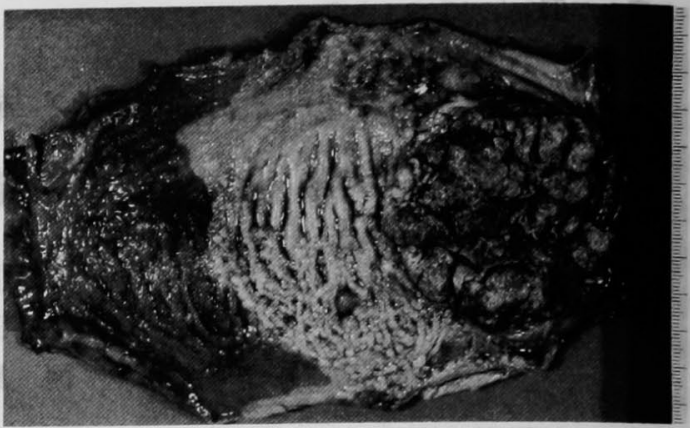

図3摘出標本所見

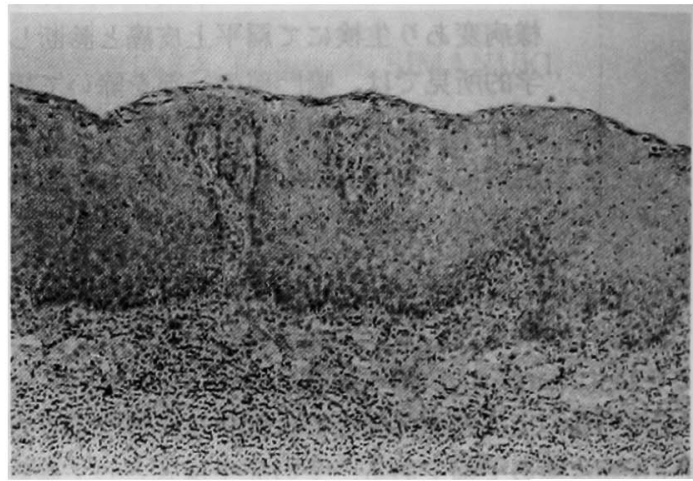

図 4a 病理組織学的所見 (異所性扁平上皮組織, H.E. 染色，4 倍）：基底膜への浸潤，核の異型性は証めな w.

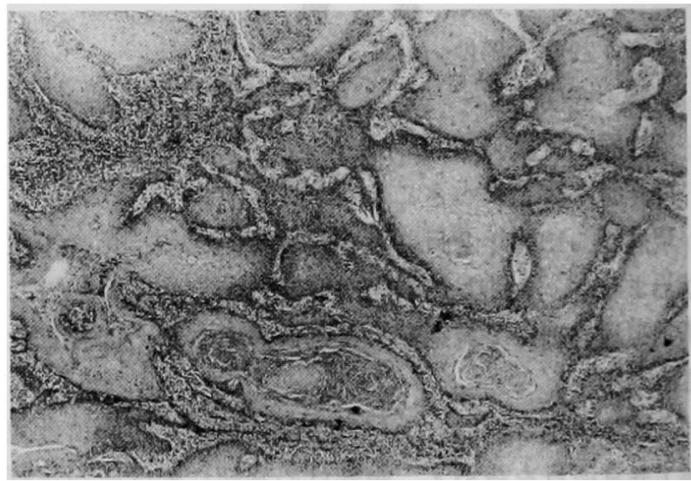

図 4b 病理組織学的所見(扁平上皮癌, H.E. 染色, 2

倍)：索状の浸潤增殖,パールフォーメーションを証 める.

$\mathrm{INF} \beta, \mathrm{sm}, \mathrm{n}(-), \mathrm{ly}_{0}, \mathrm{v}_{0}$ であった，图 5 は病変の 広がりのシェーマで, 胃体部より底部にかけて広範に 異所性扁平上皮を認めた。噴門の一部に腺組織を認め るのみで他には腺組織, 腺癌組織を認めず, 扁平上皮 


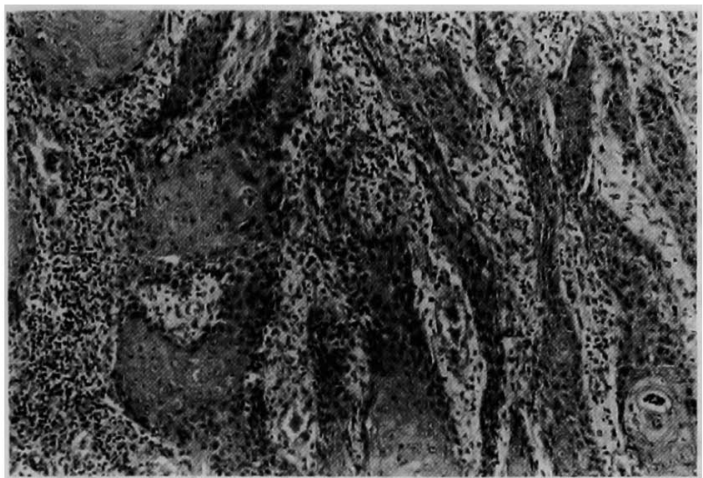

図 4c 病理組織学的所見(扁平上皮癌, H.E. 染色, 4 倍)：細胞異型, 間質に及ぶ浸潤, 孤細胞核化を認め ろ.

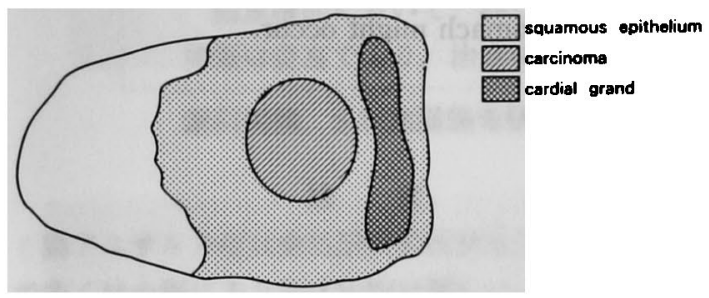

図 5 病理組織学的広がりのシェーマ

癌は，異所性扁平上皮に囲まれる形で存在していた。

\section{考察}

胃扁平上皮癌の組織発生については次の 4 説があげ られる。

(1) 腺組織が化生扁平上皮となり扁平上皮癌化した もの

(2) 異所性扁平上皮が扁平上皮癌化したもの ${ }^{177}$

(3) 腺癌が，扁平上皮化生を来したもの ${ }^{2) 4}$

(4) 食道扁平上皮癌の EC-junction を越えての進展.

これらのうち比較的広く支持されているのは，(3)の 腺癌が扁平上皮化生したとする説である。それは扁平 上皮癌が，腺扁平上皮癌の極型であると考えられるこ と, 扁平上皮癌でも一部に腺癌との移行像があること， また癌の周囲に異所性扁平上皮や扁平上皮化生を起こ した部位の認められないことなどによるものと考えら れる。

1983年の胃癌研究会アンケート調查によると，胃癌 手術症例 90,639 例中, 扁平上皮癌は85例 $(0.09 \%)$ と きわめて稀であり，胃原発の悪性腫瘍は組織像のうち 量的に最も多い組織像をもって分類されるため, 純粋 に扁平上皮癌だけを認める症例はさらに少数である。
しかも肉眼形態は，約 $80 \%$ Borrmann 2型または 3 型の進行癌であり，周囲に異所性扁平上皮，扁平上皮 化生を認めていない, 本症例においては, 扁平上皮は, 非常に広範囲であり，境界明瞭であるため(1)の扁平上 皮化とは考えにくく，腺癌組織を全く認めないため(3) の腺癌の扁平上皮化も考えにくい，また癌組織の肛門 側にも，広範に扁平上皮を認めるため食道扁平上皮癌 の進展も否定的である.よって異所性扁平上皮が，扁 平上皮癌化したものと考えられるが，50歳から60歳代 という好発年踰より非常に若年であることより組織奇 形によるものと推測される．ただし本症例には他の先 天性疾患, 奇形を認めていない，また本邦においては， 腺癌組織を認めない純粋な胃扁平上皮癌の早期癌症例 は，報告されておらず，癌の周囲に異所性扁平上皮や 扁平上皮化生を起こした症例は認められていないが, 中泉ら ${ }^{6 / 2}$ 指摘するように, 早期の段階では，これらの 細胞が存在していた可能性は考えられ, 組織発生の解 決には，多数の早期胃扁平上皮癌を発見し，検討する 必要があると考えられる。

\section{結語}

1）29歳男性, 胃扁平上皮癌の 1 例を経験したので報 告した。

2）組織学的には，腺癌組織を全く認めず，周囲に広 範な異所性扁平上皮を伴っており, 異所性扁平上皮よ り発生したものであると考えられた。

3）胃扁平上皮癌の組織発生について若干の考察を 行った。

\section{文 献}

1）水谷 伸, 左谷 稔, 小野典郎他：胃原発扁平上皮 癌の 1 例. 日臨外医会誌 $50: 2196-2200,1989$

2）道浦 準, 小林康人，一宮源太他：胃扁平上皮癌の 1 例. 和歌山医 $40: 551-556,1989$

3）三木康彰, 宗田滋夫, 上池 涉他：胃原発扁平上皮 癌の 1 例。日生病医誌 $19: 105-108,1991$

4）三村卓司, 難波康男, 浜家一雄他：胃扁平上皮癌の 1 例. 広島医 $45: 954-959,1992$

5）谷村慎哉, 東野正幸, 木下博明他：壁外性発育を呈 した胃腺扁平上皮癌の 1 例. 日臨外医会誌 52 : $383-388,1991$

6）中泉治雄, 小西二三男, 山崎 信他：胃原発の扁平 上皮癌の 1 例. 胃と腸 $18: 237-243,1983$

7) Si-Chun Ming: Tumors of the Esophagus and Stomach, Armed Forces Institute of Pathology, Washington DC, 1973, p206-207 


\title{
A CASE OF PRIMARY SQUAMOUS CELL CARCINOMA OF THE STOMACH ARISING FROM THE HETEROTOPIC SQUAMOUS EPITHELIUM WHICH OCCUPIED THE BODY AND FUNDUS OF THE STOMACH
}

\author{
Reisuke IMAJI, Kazuitsu ISHIDA, Manabu SUDA, Shintaro SHOKOKU, \\ Koji KAWASHIMA and Yasuo MIHARA \\ Department of Surgery, Sumitomobesshi Hospital
}

\begin{abstract}
A 29-yer-old man was found to have a Borr IV type-like lesion mainly in the body of the stomach by fluoroscopic and endoscopic examinations of the stomach during close examination for bloody stool. Biopsy revealed squamous cell carcinoma. Total gastrectomy with lymph node dissection was carried out. Histopathologically, excepting a portion of the cardiac part, an area from the fundus to body of the stomach was occupied with heterotopic squamous epithelium, among of which squamous cell carcinoma was found. There was no coexistence of adenocarcinoma component. According to "The General Rules for the Gastric Cancer Study", it has been defined that special type of squamous cell carcinoma arises from the metaplasia of adenocarcinoma to squamous cell carcinoma. However, in this case it is supposed that malignant change of heterotopic squamous epithelium of the stomach might occur.
\end{abstract}

